\title{
Model Pengelolaan Aset Wakaf Berbasis Profesionalisme Nadzir di Kecamatan Mamajang Kota Makassar
}

\author{
Nurul Rahmania \\ Universitas Islam Negeri Alauddin Makassar \\ nurulrahmania42@gmail.com \\ Wardatul Jannah \\ Universitas Islam Negeri Alauddin Makassar \\ wardatuljannah025@gmail.com \\ A. Syathir Sofyan \\ Universitas Islam Negeri Alauddin Makassar \\ a.syathir@uin-alauddin.ac.id
}

\begin{abstract}
This study seeks to provide an overview of an effective strategy for waqf asset management through a model recommendation in Mamajang District, Makasar City. The low quality of human resources, in this case is nadzir in managing waqf assets, causes waqf to be unproductive in Indonesia. Therefore, the purpose of this study is to provide an overview to the parties concerned, in this case waqf, regarding the unproductive nature of waqf in Indonesia so far so that it can be taken into consideration for the increase of waqf in the future. This type of research is descriptive qualitative. The results obtained are Nazhir in the district. Mamajang does not carry out its duties according to the existing law. The donation process carried out in the district. Mamajang is only intended for the construction of religious facilities and there are still waqf lands that have not been certified due to problems with Nazhir in managing land certificates that do not exist.
\end{abstract}

Keywords: waqf, management, empowerment

\section{Latar Belakang}

Berdasarkan cara pengelolaannya, tanah wakaf dikelola oleh tiga tipe nazhir, diantaranya: 1) pengelolaan wakaf secara tradisional, artinya dana wakaf dikelola dan ditempatkan hanya semata-mata sebagai ajaran murni ibadah semata. Seperti digunakan untuk membangun masjid, mushala, kuburan, dan madrasah. 2) pengelolaan wakaf secara semi tradisional, pada tipe ini harta wakaf dikelola dengan masih tradisional, 
namun para pengelola wakaf sudah mulai memahami dalam mengembangkan harta wakaf secara lebih produktif dengan tingkat kemampuan dan manajerial yang masih terbatas. 3) pengelolaan wakaf secara professional, yang mana dalam tipe ini, nadzir dituntut agar mampu memaksimalka harta wakaf untuk kepentingan yang lebih produktif lagi dan pengelolaannya dilakukan secara professional dan mandiri. ${ }^{1}$

Dari ketiga tipe nadzir yang telah dipaparkan tersebut, maka tipe nadzir yang ada di Indonesia berada pada tipe pertama yaitu harta wakaf masih dikelola secara tradisional. ${ }^{2}$ Padahal berdasarkan data BWI luas tanah wakaf di Indonesia mencapai 4.359.443.170 $\mathrm{m} 2$ yang tersebar di seluruh wilayah provinsi. Diantara jumlah tersebut tanah wakaf yang sudah bersertifikat adalah 287.160 lokasi dan belum bersertifikat sekitar 148.447. sehingga jumlah wakaf yang sudah bersertifikat lebih dominan dibanding yang belum bersertifikat. Namun ternyata pengelolaannya masih dilakukan secara tradisional. ${ }^{3}$

Di kota Makassar misalnya, tepatnya di Kec. Mamajang, yang mana harta benda wakaf kebanyakan digunakan untuk membangun masjid. Berdasarkan data Dirjen Bismas Islam Direktorat Urusan Agama Islam dan Pembinaan Syariah, mencatat bahwa luas tanah di Kec. Mamajang yang digunakan untuk membangun masjid adalah $8.798 \mathrm{~m}$ yang tersebar di 27 lokasi. ${ }^{4}$ Padahal menurut Sayyi Baqid bahwa segala macam benda yang bersifat tetap, maupun bergerak seperti perlengkapan rumah, bukubuku, mashahif, senjata, kendaraan dan sebagainya dapat dijadikan sebagai objek wakaf bahkan benda yang diperdagangkan dan dimanfaatkan, juga boleh dijadikan sebagai objek wakaf. ${ }^{5}$

Dengan adaya data tersebut, maka seharusnya pengelolaan tanah wakaf baik di Indonesia maupun yang ada di kota Makassar dapat digunakan secara produktif bukan hanya diperuntukkan untuk membangun masjid namun juga dapat dikelola sesuai dengan kebutuhan masyakat di era perkembangan sekarang ini. Dan juga masih banyaknya

${ }^{1}$ Badan Wakaf Indonesia (BWI), “Aset Wakaf Sangat Besar Tapi Belum Produktif” Situs Resmi Badan Wakaf Indonesia, https://bwi.or.id/index.php/ar/publikasi/artikel/264-aset-wakaf-sangatbesar-tapi-belum-produktif.html (16 Juni 2019).

2 Agus Triyanti, (2014), "Problematika Pengelolaan Tanah Wakaf: Konsep Klasik Keterbatasan Inovasi Pemanfaatannya di Indonesia”, Jurnal Hukum IUS QUI IUSTM, 21(4),.584.

${ }^{3}$ Badan Wakaf Indonesia (BWI), "Data Tanah Wakaf Seluruh Indonesia", Situs Resmi Badan Wakaf Indonesia, https://bwi.or.id/index.php/en/tentang-wakaf/data-wakaf/data-wakaf-tanah.html (16 Juni 2019).

4 Sistem Informasi Masjid (SISMAS), "Daftar Profil Masjid" Situs Resmi Sismas. http://simas.kemenag.go.id/index.php/profil/masjid/page/40/?kecamatan_id=5558 (15 Juni 2019)

${ }^{5}$ Abdul Haris Naim (2017), "Pengembangan Obyek Wakaf Dalam Fiqig Islam Dan Hukum Positif Di Indonesia”, Ziswaf, 4(2), 249. 
masyarakat yang tidak paham mengenai kata wakaf itu sendiri sehingga perlu adanya sosialisasi yang dilakukan agar masyarakat dapat paham dan dapat merealisasikannya guna meningkatan pembangunan yang ada di Indonesia.

\section{Landasan Teori}

\section{Tinjauan Umum tentang Wakaf}

Kata wakaf berasal dari bahasa Arab yaitu waqf, yang merupakan nama terbitan dari kata kerja waqafa, yang memiliki berbagai makna mengikut tujuan dan penggunaan ayat itu sendiri. Menurut bahasa, waqf memberi makna berhenti (السكن), mencegah ( المنع) dan menahan (الحبس). Sedangkan dalam hal istilah, wakaf memiliki banyak pengertian salah satunya adalah menurut Muhammad Abid Abdullah al-Kabisi dalam Suwaidi, bahwa wakaf merupakan pemilikan dan pemeliharaan dari harta benda tertentu yang digunakan untuk kemanfataan social dan ditetapkan dengan maksud untuk mencegah penggunaan harta benda wakaf diluar tujuan khusus yang telah ditetapkan. ${ }^{7}$

Undang-Undang Nomor 41 Tahun 2004 mengartika wakaf sebagai perbuatan hukum wakif dalam memisahkan dan menyerahkan sebagian harta benda miliknya untuk digunakan selamanya atau untuk jangka waktu tertentu sesuai dengan kepentingan guna keperluan ibadah atau kesejahteraan umum menurut syari'at. ${ }^{8}$ Dalam pandangan An- Nawawi, Harta benda wakaf juga sering disebut sebagi obyek wakaf yang mana didefinisikan sebagai harta tertentu yang dapat diambil manfaatnya. ${ }^{9}$ Sayyid Sabiq dalam Naim, juga menjelaskan bahwa benda, baik itu yang bersifat tetap (al-Uqar), maupun yang bergerak (al-Manqul) seperti perlengkapan rumah, mashahif, buku- buku, senjata, dan kendaraan dapat dijadikan sebagai objek wakaf dan setiap benda yang boleh diperdagangkan dan dimanfaatkan (dengan tetap kekal zatnya), juga boleh dijadikan sebagai objek wakaf. ${ }^{10}$

Menurut jumhur ulama terdapat 4 rukun wakaf, yaitu: 1) orang yang berwakaf (waqif), 2) orang yang menerima wakaf (mawquf 'alayh), 3) harta yang diwakafkan (mawqufbih), dan 4) sighat (ikrar wakaf), kecuali Abu Hanifah yang tidak mensyaratkan adanya sighat. Adapun syarat

6 Asmak Ab Rahman (2019), "Peranan Wakaf dalam Pembangunan Ekonomi Umat Islam dan Aplikasinya di Malaysia”, Jurnal Syariah, 17(1),114.

7 Ahmad Suwaidi, "Wakaf dan Penerapannya di Negara Muslim", Jurnal Ekonomi dan Hukum Islam 1(2), 20.

${ }^{8}$ Republik Indonesia, Undang-Undang Nomor 41 Tahun 2004, bab I, pasal 1.

${ }^{9}$ Sudirman (2010), "Studi Perbandingan Obyek Wakaf Menurut Fiqih Dan Undang-Undang Wakaf”, Fakultas Syariah UIN Maliki Malang, 1(2), 134.

${ }^{10}$ Abdul Haris Naim (2017), "Pengembangan Obyek Wakaf Dalam Fiqig Islam Dan Hukum Positif Di Indonesia", Ziswaf, 4(2), 249. 
waqif adalah baligh (cukup umur); merdeka (benar-benar pemilik harta yang diwakafkan); berakal sehat; dan cerdas (kematangan dalam bertindak). ${ }^{11}$

Menurut Peraturan Pemerintah Republik Indonesia benda yang tidak bergerak meliputi: ${ }^{12}$

a. Hak atas tanah didasarkan pada ketentuan Peraturan Perundang undangan baik yang telah atau yang belum terdaftar;

b. Bagian bangunan yang berdiri diatas tanah ataupun yang belum dibangun telah diatur sebagaimana dimaksud pada huruf a;

c. tanaman ataupun benda lain yang berkaitan dengan tanah;

d. hak milik atas satuan rumah susun sesuai dengan ketetapan dalam Peraturan Perundang-undangan; dan

e. benda tidak bergerak lain yang sesuai dengan ketentuan prinsip syariah dan Peraturan Perundang-undangan.

Adapun benda yang bergerak selain uang yaitu: ${ }^{13}$

a. Benda yang digolongkan sebagai benda bergerak karena memiliki sifat yang dapat berpindah atau dipindahkan atau karena didasarkan pada ketetapan undang-undang.

b. Benda bergerak yang dapat dihabiskan dan yang tidak dapat dihabiskan karena pemakaian.

c. Benda bergerak yang dapat dihabiskan karena pemakaian tidak dapat diwakilkan, kecuali air dan bahan bakar minyak yang persediaannya berkelanjutan.

d. Benda bergerak yang tidak dapat dihabiskan karena pemakaian dapat diwakafkan dengan memperhatikan ketentuan prinsip syariah.

Adapun benda bergerak karena sifatnya yang dapat diwakafkan meliputi: ${ }^{14}$

a. kapal;

b. pesawat terbang;

c. kendaraan bermotor;

d. mesin atau peralatan industri yang tidak tertancap pada bangunan;

e. logam dan batu mulia; dan/atau

f. benda lainnya yang tergolong sebagai benda bergerak karena sifatnya dan memiliki manfaat jangka panjang.

Tugas dan Kedudukan Nadzir

\footnotetext{
${ }^{11}$ Ahmad Suwaidi (2018), Wakaf dan Penerapannya di Negara Muslim, Jurnal Ekonomi dan Hukum Islam, 1, (2), 22.

${ }^{12}$ Republik Indonesia, Peraturan Pemerintah Nomor 42 Tahun 2006, bab III, pasal 16.

${ }^{13}$ Republik Indonesia, Peraturan Pemerintah Nomor 42 Tahun 2006, bab III, pasal 19.

${ }^{14}$ Republik Indonesia, Peraturan Pemerintah Nomor 42 Tahun 2006, bab III, pasal 20.
} 
Dalam hal perwakafan, nadzir merupakan salah satu pihak yang bertugas untuk menerima harta benda wakaf dari si pemberi harta wakaf untuk dapat dikelola dan dikembangkan sesuai peruntukannya. Wakaf dalam UU No 41 Tahun 2004 telah mengatur berbagai persoalan nadzir dengan sangat rinci. Hal tersebut menunjukkan bahwa kedudukan nadzir merupakan suatu hal yang sangat diperhatikan dalam UU dan juga terdapat kesan kuat bahwa eksistensi wakaf dan pemberdayaannya sangat tergantung pada nadzir tersebut. Tugas lain dari nadzir yaitu berkewajiban untuk dapat mengerjakan segala sesuatunya agar dapat menjaga dan mengelola harta wakaf. ${ }^{15}$

Achmad Djunaidi, dkk dalam Kasdi, menjelaskan bahwa dalam mengukur seberapa besar profesionalitas suatu nadzir adalah dengan mengetahui apakah nadzir itu amanah (dapat dipercaya), shiddiq (jujur), fathanah (cerdas), dan tablig (transparan). Adapun sumber daya nadzir yang amanah adalah: 1) terdidik dan bermoral tinggi, 2) unggul dalam hal keterampilan dan bersaing, 3) mempunyai kemampuan dalam hal pembagian kerja, 4) adil dan dapat melaksanakan kewajibannya, dan 5) mempunyai standar dalam operasional kerja yang terarah dan jelas. ${ }^{16}$

\section{Metode Penelitian}

Penelitian ini merupakan penelitian lapangan yang didekati secara kualitatif ${ }^{17}$ dengan mengungkap kebenaran melalui fakta di masyarakat. ${ }^{18}$ Penelitian ini termasuk dalam jenis penelitian case study dokumentatif, di mana penelitian lapangan yang kualitatif lebih banyak disorot dari aspek observasi dan wawancara kepada kepala kecamatan lokasi penelitian dengan mengambil setting penelitian aktual, peneliti sebagai pengamat tunggal, data bersifat deskriptif dan analisa datanya menggunakan deduktif. ${ }^{19}$

Pengambilan data diambil dari dua sumber; primer dan sekunder. ${ }^{20}$ Data primer diperoleh dari observasi dan wawancara dengan Camat Mamajang yang dikira pemahaman pengelolaan wakaf di atas rata-rata,

\footnotetext{
${ }^{15}$ Abdurrahman Kasdi, Peran Nadzir dalam Pengembangan Wakaf, Jurnal Zakat dan Wakaf 1, No. 2, Desember (2014), h.218.

${ }^{16}$ Abdurrahman Kasdi, Peran Nadzir dalam Pengembangan Wakaf, Jurnal Zakat dan Wakaf 1, No. 2, Desember (2014), h.219.

17 Cik Hasan Bisri, Pilar-Pilar Penelitian Hukum Islam dan Pranata Sosial. Jakarta : Grafindo Persada, 2004, hlm. 56

18 Peter Mahmud Marzuki, Penelitian Hukum, Cet. Ke-7. Jakarta: Kencana, 2011, hlm.132.

19 Nurul Zuriah, Metodologi Penelitian Sosial dan Pendidikan. Jakarta : Bumi Aksara, 2006, hlm. 92.

${ }^{20}$ Julia Brenen, Memadu Metode Penelitian : Kualitatif dan Kuantitatif. Yogyakarta : Pustaka Pelajar, 2005, hlm. 11.
} 
selain itu, data primer juga didapat dari observasi terhadap aktifivas fenomena pemberdayaan umat melalui lembaga wakaf. Sementara data sekunder diambil buku, jurnal, penelitian terdahulu, surat kabar dan artikel lain yang memiliki keterkaitan. ${ }^{21}$

Teknik pengumpulaln data dilakukan melalui observasi dan wawancara, ${ }^{22}$ dengan mengambil sampel secara acak (purposive sampling) yaitu sampel yang diambil atas dasar pertimbangan tententu. ${ }^{23}$ Pada tahap akhir, dilakukan filterasi validitas data, yang dalam penelitian ini menggunakan triangulasi sumber, yaitu membandingkan antara narasumber yang satu dengan lainnya untuk kemudian dicocokan. ${ }^{24}$ Perlu diketahui, bahwa teori yang digunakan dalam mengungkap realitas di masyarakat, penulis menggunakan teori ethnometodologi.

\section{Hasil Penelitian}

Kecamatan Mamajang merupakan salah satu dari 15 Kecamatan di Kota Makassar yang berbatasan di sebelah utara dengan Kecamatan Makassar dan Kecamatan Ujung Pandang, disebelah timur dengan Kecamatan Rappocini, disebelah selatan dengan Kecamatan Tamalate dan di sebelah Barat dengan Kecamatan Mariso. Sebanyak 13 kelurahan di Kecamatan Mamajang merupakan daerah bukan pantai dengan ketinggian dibawah 500 meter dari permukaan laut. Menurut jaraknya, letak masing-masing kelurahan ke ibukota kecamatan bervariasi antara 1$2 \mathrm{~km}$.

Kecamatan mamajang terdiri dari 13 kelurahan dengan luas wilayah 2,25 km². Dari luas wilayah tersebut tercatat bahwa Kelurahan Bonto Biraeng memiliki wilayah terluas yaitu $0,63 \mathrm{~km}^{2}$, terluas kedua adalah Kelurahan Sambung Jawa dengan luas wilayah 0,30 km², sedangkan yang paling kecil luas wilayahnya adalah Kelurahan Tamparang Keke yaitu 0,05 $\mathrm{km}^{2}$. Kegiatan pemerintahan di Kecamatan Mamajang dilaksanakan oleh sebanyak 246 orang aparat/pegawai negeri, berasal dari berbagai dinas/instansi pemerintah, yang terdiri atas 83 orang laki-laki dan 163 orang perempuan.

Jumlah penduduk tahun 2018 sebesar 61.007 jiwa, dan tahun 2015 sebesar 60.779 jiwa, yang berarti penduduk Kecamatan Mamajang

${ }^{21}$ Lexy J. Meleong, Metodologi Penelitian Kualitatif Edisi Revisi, Cet. Ke-22. Bandung : PT REMAJA ROSDAKARYA, 2006, hlm. 225.

${ }^{22}$ Gabriel Amin Silalahi, Metode Penelitian dan Studi Kasus. Sidoarjo : Citra Media, 2003, hlm. 57.

${ }^{23}$ Burhan Bungin, Penelitian Kualitatif: Komunikasi, Ekonomi, Kebijakan Publik, dan Ilmu Sosial lainnya. Jakarta : Kencana Prenada Media Group, hlm. 108.

${ }^{24}$ Husaini Usman dan Purnomo Akbar, Metodelogi Penelitian Sosial, Cet. Ke-6. Jakarta: Bumi Aksara, 2006, hlm. 73. 
menurun sebesar 0.37 persen. Berdasarkan jenis kelamin tampak bahwa jumlah penduduk laki-laki sekitar 29.884 jiwa dan perempuan sekitar 31.123 jiwa. Dengan demikian rasio jenis kelamin adalah sekitar 96 yang berarti setiap 100 orang penduduk perempuan terdapat sekitar 96 orang penduduk laki-laki. Kelompok umur 20-24 tahun tercatat mempunyai populasi terbanyak yaitu 7.251 jiwa menyusul umur 15-19 tahun sebesar 6.093 jiwa, sedangkan kelompok umur 75 tahun keatas hanya 832 jiwa. Ditinjau dari Agama yang dianut, tercatat bahwa sebagian besar penduduk Kecamatan Mamajang adalah beragama Islam, mayoritas dari total penduduk. Jumlah fasilitas ibadah di Kecamatan Mamajang cukup memadai karena terdapat 34 buah Mesjid, 3 buah Langgar/Mushallah dan 10 buah Gereja.

Kantor Urusan Agama (KUA) Kecamatan Mamajang tidak memiliki data terkait sejarah berdirinya KUA tersebut. Saat mengadakan penelitian disana, tidak ada satu-pun pegawai yang dapat memberikan informasi terkait sejarah berdirinya KUA tersebut dengan alasan mereka memang tidak mengetahuinya. Serta tidak ditemukannya arsip atapun catatan mengenai sejarah berdirinya KUA Kecamatan. Mamajang.

\section{Bagan I}

Struktur KUA Kecamatan Mamajang

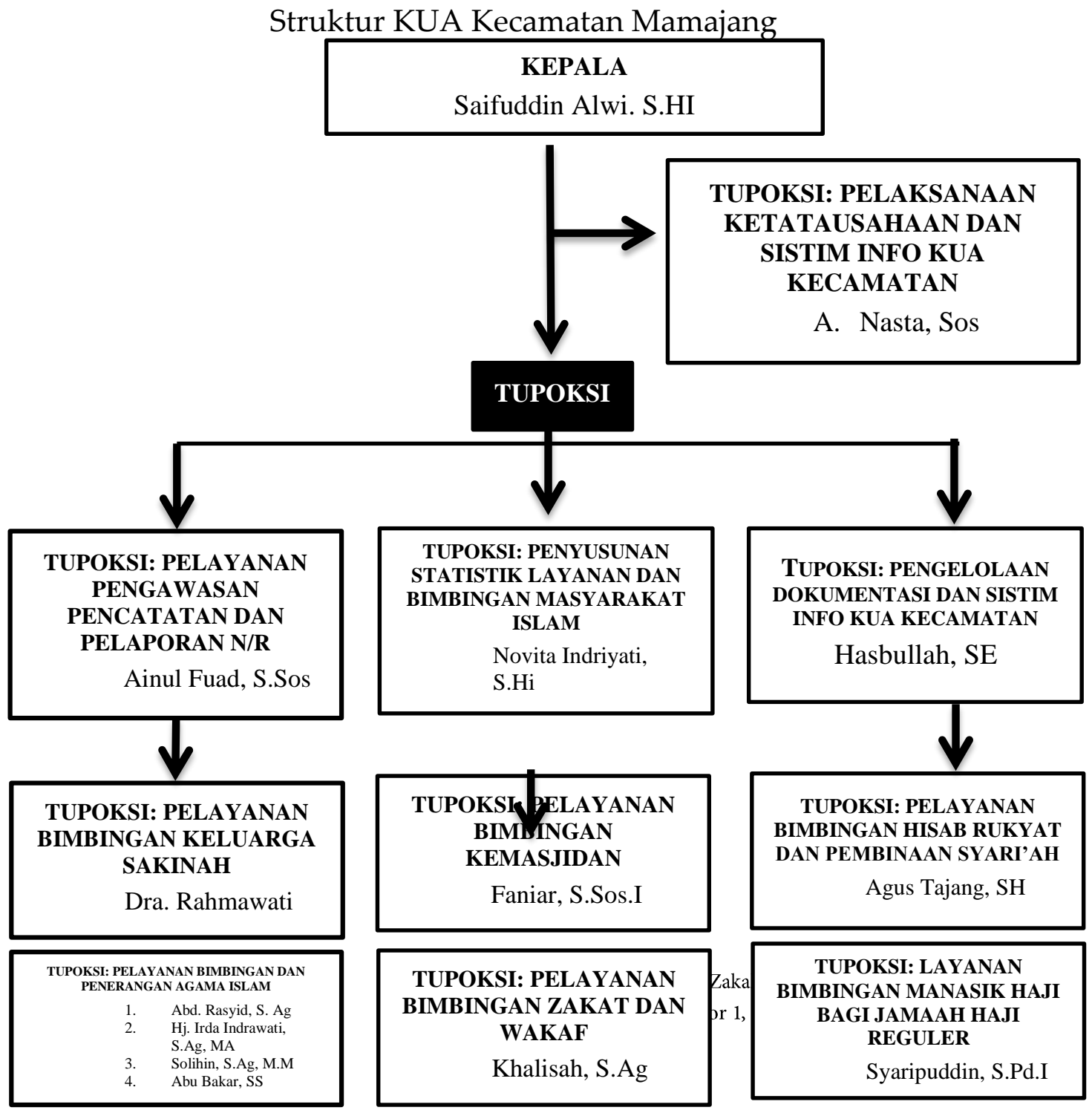


Sumber: KUA Kecamatan Mamajang Tahun 2017 (Berdasarkan KMA No. 34 Tahun 2016)

VISI

Perwakafan yang ada di Kecamatan Mamajang telah berlangsung sejak lama. Aset tanah wakaf yang ada berkisar tanah wakaf dan telah diperuntukkan untuk masjid, mushallah, perguruan Islam, Kuburan dan lain-lain. Berikut daftar tanah wakaf yang ada di kecamatan Mamajang:

\section{Tabel I}

Tanah Wakaf Kecamatan Mamajang

\begin{tabular}{|c|l|c|c|c|}
\hline No & \multicolumn{1}{|c|}{ Kelurahan } & $\begin{array}{c}\text { Luas } \\
\text { Tanah }\left(\mathrm{M}^{2}\right)\end{array}$ & $\begin{array}{c}\text { Jumlah } \\
\text { Lokasi }\end{array}$ & $\begin{array}{c}\text { Sudah } \\
\text { Sertifikat }\end{array}$ \\
\hline 1 & Baji Mappakasunggu & 1212 & 6 & 1 \\
\hline 2 & Maricaya Selatan & 760 & 6 & - \\
\hline 3 & Pa'Batang & 1248 & 2 & - \\
\hline 4 & Bonto Biraeng & 1059 & 4 & 1 \\
\hline 5 & Labuang Baji & 225 & 2 & - \\
\hline 6 & Mamajang Dalam & 950 & 1 & - \\
\hline 7 & Mamajang Luar & 1816 & 4 & - \\
\hline 8 & Bonto Lebang & 436 & 2 & - \\
\hline 9 & Karang Anyar & 372 & 3 & - \\
\hline 10 & Sambung Jawa & 2185 & 5 & 1 \\
\hline 11 & Tamparang Keke & 977 & 4 & 1 \\
\hline 12 & Mandala & 1652 & 3 & - \\
\hline 13 & Parang & & 1 & - \\
\hline
\end{tabular}

Sumber: KUA Kecamatan Mamajang

Dari data yang diperoleh, dapat dilihat bahwa cukup banyak tanah wakaf yang ada di Kecamatan Mamajang dan akan sangat bermanfaat apabila tanah wakaf tersebut dikelola secara profesional. Tanah wakaf yang ada di atas mayoritas adalah tanah wakaf yang ada sejak lama.

\section{Peran Nazhir dalam Pengelolaan dan Pemberdayaan Aset Wakaf}

Pengeloaan dan Pemberdayan harta benda wakaf diberikan sepenuhnya kepada nazhir, karena nazhir merupakan orang yang paling bertanggung jawab terhadap pengelolaan dan pemberdayaan harta benda wakaf. Nazhir yang diharapkan mampu untuk mengelola dan memberdayakan harta benda wakaf adalah nazhir professional, baik bersifat perorangan maupun nazhir organisasi. Nazhir professional adalah 
nazhir yang dituntut mampu memaksimalkan harta wakaf untuk kepentingan yang lebih produktif dan dikelola secara profesional dan mandiri. ${ }^{25}$

Adapun penelitian ini mengambil 9 informan yang berprofesi sebagai nazhir dan 1 informan yang berprofesi sebagai Staff Pelayanan Bimbingan Zakat dan Wakaf di KUA Kecamatan Mamajang Kota Makassar. Dari data ini peneliti membuat beberapa bagian yaitu diantaranya, nama, umur serta alamat para subjek yang akan diteliti. Harta benda wakaf di Kecamatan Mamajang kebanyakan berupa tanah yang hanya diperuntukkan untuk membangun sebuah masjid. Adapun KUA yang dibawah naungan BWI dalam hal ini untuk mengurusi wakaf jika ada yang ingin mendaftarkan wakafnya ataupun ingin berganti nazhir. Namun, KUA Kecamatan Mamajang dalam kurung waktu lima tahun terkahir menyatakan bahwa tidak ada satupun orang yang datang untuk mendaftarkan harta benda yang diwakafkan ataupun untuk melakukan prosedur pergantian nazhir. Hal itu sesuai dengan apa yang disampaikan oleh Ibu Khalisah:

"Selama saya bekerja disini belum ada yang mendaftarkan harta benda wakafnya. Juga tidak ada satupun nazhir yang datang, baik dalam rangka urusan pergantian nazhir ataupun meminta penyuluhan terkait pengelolaan harta benda wakaf" 26

Adapun data harta benda wakaf yang kami peroleh dari Kecamatan Mamajang merupakan data yang sudah sangat lama. Itupun data yang kami peroleh tidak jelas tertera alamatnya sehingga kami tidak bisa melakukan penelitian langsung ke lokasi harta benda wakaf. Berikut ini data informan penelitian yang kami dapatkan dapatkan:

\section{Tabel 2}

Data informan penelitian

\begin{tabular}{|c|c|c|c|}
\hline $\begin{array}{l}\mathbf{N} \\
\mathbf{0}\end{array}$ & Nama & Umur & Alamat \\
\hline 1 & $\begin{array}{l}\text { H. Muhammad Sri } \\
\text { Fatta }\end{array}$ & $\begin{array}{l}65 \\
\text { tahun }\end{array}$ & Jl. Veteran Selatan Kel. Mandala \\
\hline 2 & Dr. Eli Hasmin & 50 & Jl. Harimau Kel. Maricaya Selatan \\
\hline
\end{tabular}

\footnotetext{
${ }^{25}$ Badan Wakaf Indonesia (BWI), “Aset Wakaf Sangat Besar Tapi Belum Produktif” Situs Resmi Badan Wakaf Indonesia, https://bwi.or.id/index.php/ar/publikasi/artikel/264-aset-wakaf-sangatbesar-tapi-belum-produktif.html (16 Juni 2019).

${ }^{26}$ Khalisah (55 tahun), Staff Pelayanan Bimbingan Zakat dan Wakaf KUA Kecamatan Mamajang, Wawancara, Mamajang, 2 Juli 2019.
} 


\begin{tabular}{|c|c|c|c|}
\hline & & Tahun & \\
\hline 3 & Marzuki & $\begin{array}{l}60 \\
\text { Tahun }\end{array}$ & $\begin{array}{l}\text { Jl. Baji Ateka Lr.5 Kel. Baji } \\
\text { Mappakasunggu }\end{array}$ \\
\hline 4 & Syahril & $\begin{array}{l}50 \\
\text { Tahun }\end{array}$ & $\begin{array}{l}\text { Jl. Cendrawasih Kel. Tamparang } \\
\text { Keke }\end{array}$ \\
\hline 5 & Nur Alam Saleh & $\begin{array}{l}59 \\
\text { Tahun }\end{array}$ & Jl. Baji Nyawa Kel. Karang Anyar \\
\hline 6 & Ustadz Akmal & $\begin{array}{l}50 \\
\text { Tahun }\end{array}$ & $\begin{array}{l}\text { Jl. Veteran Selatan Lr. } 3 \text { Kel. Bonto } \\
\text { Lebang }\end{array}$ \\
\hline 7 & Ustadz Muhammad & $\begin{array}{l}53 \\
\text { Tahun }\end{array}$ & $\begin{array}{l}\text { Jl. Cendrawasih } \\
\text { Mattoanging Kel. Pa'batang }\end{array}$ \\
\hline 8 & Drs. H. Sanrusseng & $\begin{array}{l}75 \\
\text { Tahun }\end{array}$ & Jl. Tupai Kel. Bontobiraeng \\
\hline 9 & Isla Idris & $\begin{array}{l}51 \\
\text { Tahun }\end{array}$ & Jl. Kakatua 2 Kel. Parang \\
\hline
\end{tabular}

Sumber: data diperoleh melalui wawancara

Data ini diperoleh melalui wawancara di lapangan. Peneliti mewawancarai sepuluh informan. Sembilan diantaranya adalah sebagai nazhir yang mengabaikan undang-undang perwakafan dalam mengurus tanah wakaf dan satu informan sebagai Staff Pelayanan Bimbingan Zakat dan Wakaf (KUA Kecamatan Mamajang). Informan yang paling muda adalah berumur 43 tahun dan yang paling tua berumur 75 tahun.

Adapun rumusan pertanyaan yang peneliti tanyakan kepada informan, pertama yaitu bagaimana nazhir mengelola dan mengembangkan harta benda wakaf. Kedua, program-program apa saja yang dilaksanakan dalam mengembangkan . Ketiga, apa saja kendala yang dihadapi dalam mengelola harta benda wakaf.

\section{Nazhir}

a. Muhammad Sri Fatta selaku Nazhir di Masjid Babussalam

Tanah wakaf yang diatasnya didirikan sebuah masjid Babussalam ini terletak di Jalan Veteran Selatan Kelurahan Mandala Kecamatan Mamajang. Tanah wakaf ini merupakan tanah wakaf dari H. Nazhir yang diberikan pada tahun 2001. Adapun pengelola tanah wakaf ini (nazhir) ialah H Muhammad Sri Fatta yang yang diangkat menjadi nazhir setahun setelah tanah tersebut diwakafkan. Sebagaimana yang disampaikan oleh beliau bahwa: 
"Saya diangkat menjadi nazhir sekitar setahun setelah tanah diwakafkan" 27

H. Muhammad Sri Fatta sebagai seorang nazhir mengatakan bahwa tanah wakaf yang dibangunkan sebuah masjid diatasnya ini telah memiliki sertifikat. Namun sertifikat tersebut dipegang oleh anak $\mathrm{H}$. Nazhir (wakif). Sebagaimana yang disampaikan oleh beliau bahwa:

"Tanah wakaf ini ada sertifikatnya tapi dipegang sama anaknya $\mathrm{H}$. Nazhir" 28

Selain sertifikat yang tidak berada ditangan nazhir, pengelolaan tanah wakaf ini masih bersifat professional. Karena hanya diperuntukkan untuk membangun sebuah masjid yang dilengkapi dengan adanya Taman Pendidikan Al-Qur'an di masjid tersebut. Sebagiamana yang dinyatkan oleh H. Muhammad Sri Fatta bahwa:

"Program pengembangan tanah wakaf ini seperti diadakannya TPA" 29

Pengembangan tanah wakaf ini hanya mengandalkan dana dari kotak amal karena masjid yang dibangun diatas tanah wakaf tersebut tidak memiliki donatur. Selain itu adanya perbedaan pendapat antar para pengurus masjid juga menjadi salah satu penghalang pemberdayaan tanah wakaf. Sebagaimana yang disampaikan oleh H. Muhammad Sri Fatta bahwa:

"Masjid ini tidak memakai donatur dalam mengelola tanah wakaf hanya mengandalkan kotak amal saja serta banyaknya perbedaan pendapat dari para pengurus dan masalah dana yang kadang tidak lancar menghambat pemberdayaan tanah wakaf" 30

Jadi, selain masalah internal pengurus masjid yang menghambat pemberdayaan tanah wakaf, ternyata masalah dana juga menjadi kendala pemberdayaan tanah wakafnya.

b. Dr. Eli Hasmin selaku Nazhir di Masjid Baitul Aman

${ }^{27}$ H. Muhammad Sri Fatta (65 tahun), Nazhir Masjid Babussalam Kelurahan Mandala, Wawancara, 30 Juni 2019.

${ }^{28}$ H. Muhammad Sri Fatta (65 tahun), Nazhir Masjid Babussalam Kelurahan Mandala, Wawancara, 30 Juni 2019.

${ }^{29}$ H. Muhammad Sri Fatta (65 tahun), Nazhir Masjid Babussalam Kelurahan Mandala, Wawancara, 30 Juni 2019.

${ }^{30}$ H. Muhammad Sri Fatta (65 tahun), Nazhir Masjid Babussalam Kelurahan Mandala, Wawancara, 30 Juni 2019. 
Tanah wakaf yang diatasnya dibangun Masjid Baitul Aman ini terletak di Jl. Harimau Kelurahan Maricaya Selatan Kecamatan Mamajang. Adapun wawancara dilakukan di kediaman bapak Dr. Eli Hasmin di Jl. Harimau Kelurahan Maricaya Selatan. Saat wawancara subjek cukup antusias dalam menyambut mahasiswa yang melakukan penelitian. Bapak Dr. Eli Hasmin selaku nazhir tidak mengetahui siapa yang mewakafkan dan kapan tanah tersebut diwakafkan, karna beliau hanya menerima atau meneruskannya dari kepengurusan sebelumnya. Bahkan bapak Dr. Eli Hasmin selaku nazhir tidak mengetahui apakah tanah wakaf ini memiliki sertifikat atau tidak. Sebagaimana yang disampaikan oleh pak Eli Hasmin:

"Saya tidak tahu siapa yang mewakafkan dan kapan diwakafkan karna saya hanya terima dari kepengurusan sebelumnya. Saya juga tidak tau apakah tanah wakaf ini memiliki sertifikat atau tidak. Tapi yang saya tau itu masjid Baitul Aman ini adalah masjid tertua di Kecamatan Mamajang." 31

Sejak tahun 2017 Dr. Eli Hasmin menjadi nazhir masjid Baitul Aman, sejak saat itupun masjid ini sering mengadakan renovasi. Adapun bantuan yang didapatkan salah satunya adalah bantuan semen dari Bosowa yang didapat melalui usaha-usaha pengajuan proposal. Selain sering diadakan renovasi, pada hari raya Idul Adha juga banyak yang berqurban di Masjid Baitul Aman. Sebagaimana yang disampaikan oleh Dr. Eli Hasmin bahwa:

"Sampai saat ini terus melakukan renovasi-renovasi pada masjid. Sekarang sementara di renovasi terus, kemarin ada bantuan semen dari bosowa tinggal tunggu pasir baru di renovasi. Saya juga sering mengirim proposal-proposal bantuan dan Alhamdulillah banyak yang memberi bantuan seperti bosowa. Semenjak saya jadi nazhir Alhamdulillah banyak yang berqurban di masjid ini jadi setiap idul Adha sekitar 10 ekor sapi biasanya." 32

Sejak mengelola masjid Baitul Aman ini, bapak Eli Hasmin juga mengalami kesulitan untuk menyatukan masyarakat sekitar dikarenakan kebanyakan dari mereka beragama non muslim dan dana yang terkumpul dari masyarakat biasanya lambat disetor kepada pengurus. Sebagaimana yang dikatakan oleh Dr. Eli Hasmin bahwa:

\footnotetext{
${ }^{31}$ Eli Hasmin (50 tahun), Nazhir Masjid Baitul Aman Kelurahan Maricaya Selatan, Wawancara, 2 Juli 2019.

${ }^{32}$ Eli Hasmin (50 tahun), Nazhir Masjid Baitul Aman Kelurahan Maricaya Selatan, Wawancara, 2 Juli 2019.
} 
"Susah menyatukan masyarakat sekitar karena kebanyakan beragama non muslim, dana yang masuk cukup memadai namun terlambat diberikan ke pengurus atau bendahara masjid." 33

Adapun program-program yang dijalankan oleh Pak Dr. Eli Hasmin sejak menjadi nazhir dimasjid ini yakni, kegiatan TPA, Majelis Taqlim dan merayakan hari besar Islam. Sebagaimana yang disampaikan oleh Dr. Eli Hasmin:

"Pogram yang dilakukan adalah renovasi masjid, serta pemberdayaan masjid dengan membuat kegiatan TPA, Majelis Taqlim, merayakan hari-hari raya besar Islam." 34

Jadi, sejak pak Eli Hasmin menjadi nazhir, belum ada programprogram untuk mengembangkan tanah wakaf ini kearah yang lebih produktif.

\section{c. Marzuki Selaku Nazhir Masjid Baitul Mu'minin}

Tanah wakaf yang diatasnya dibangun masjid Baitul Mu'minin ini bertempat di Jalan Baji Ateka lorong 5 Kelurahan Baji Mappakasunggu Kecamatan Mamajang. Tanah wakaf ini merupakan pemberian dari H.Baji yang diwakafkan sekitar tahun 70-an. Tanah wakaf ini telah bersertifikat dan sertifikatnya dipegang oleh bapak Marzuki. Bapak Marzuki menjadi nazhir sejak tahun 1996. Sebagaimana yang disampaikan oleh Bapak Marzuki:

"Tanah ini diwakafkan sekitaran tahun 70-an dan sudah bersertifikat. Saya juga sudah lama menjadi pengurus sejak tahun $1996^{\prime \prime 35}$

Bapak Marzuki sangat kesusahan dalam megelola Masjid Baitul $\mathrm{Mu}^{\prime}$ minin dikarenakan tempatnya yang sempit. Terkadang banyak orang yang ingin menyembeli hewan qurbannya akan tetapi terkendala di tempat penyembelihannya. Jadi, setiap tahun hanya satu ekor hewan Qurban yang disembelih itupun hanya inisiatif dari pengurus sendiri. Sebagaimana yang disampaikan oleh bapak Marzuki:

\footnotetext{
${ }^{33}$ Eli Hasmin (50 tahun), Nazhir Masjid Baitul Aman Kelurahan Maricaya Selatan, Wawancara, 2 Juli 2019.

${ }^{34}$ Eli Hasmin (50 tahun), Nazhir Masjid Baitul Aman Kelurahan Maricaya Selatan, Wawancara, 2 Juli 2019.

${ }^{35}$ Marzuki (60 tahun), Nazhir Masjid Baitul Mu'minin Kelurahan Baji Mappakasunggu, Wawancara, 9 Juli 2019.
} 
“Qurban setiap tahun itu hanya 1 ekor itupun hanya inisiatif dari pengurus saja karena biasa banyak mau berqurban disini tapi masalahnya dimana mau disembelih tapi itu sudah cukup untuk dibagikan di warga sekitar"36

Masjid baitul mu'minin memiliki program-program yang sama dengan masjid-masjid sebelumnya yaitu TPA dan Kajian-kajian. Dalam mengelola masjid tersebut Bapak Marzuki mengalami kendala-kendala yaitu tidak pernah ada bantuan dari pemerintah. Sebagaimana yang disampaikan oleh bapak Marzuki:

“Disini ada TPA dan kajian ibu-ibu. Tidak pernah ada bantuan dari pemerintah. Mau diberi bantuan oleh baznas tapi terlalu banyak persyaratannya meminta kartu keluarga masyarakat sekitar tetapi masyarakat keras kepala tidak mau mengikuti persyaratan tersebut" 37

Sebelumnya, BAZNAS pernah menawarkan bantuan untuk masyarakat setempat tetapi masyarakat setempat yang terlalu keras kepala tidak mau mengikuti persyaratan yang diminta oleh BAZNAZ.

d. Syahril Selaku Nazhir Masjid Darul Ikhlas

Tanah wakaf yang diatasnya dibangun Masjid Darul ikhlas bertempat di Jalan Cendrawasih Kelurahan Tamparang Keke Kecamatan Mamajang. Tanah ini diwakafkan oleh H.Abdul Halim S. Adapun pengelola tanah wakaf ini adalah bapak Syaril yang sudah menjadi pengurus selama 25 tahun. Sebagaimana yang disampaikan oleh bapak Syahril:

“Tanah ini diwakafkan oleh H.Abdul Halim S sekitar tahun 50an dan sudah bersertifikat" 38

Tanah wakaf ini telah memiliki sertifikat, selain itu programprogram yang dilaksanakan oleh pengurus Masjid Darul Ikhlas diantaranya majelis taklim, TPA, Remaja Masjid, Kajian setiap malam senin, Qurban, dan buka puasa bersama pada bulan Ramadhan. Bapak Syahril mengatakan bahwa dalam mengelola Masjid Darul Ikhlas tidak merasakan kendala-kendala apapun dan terus melakukan renovasi pada masjid tersebut. Sebagaimana yang dikatakan oleh beliau:

\footnotetext{
${ }^{36}$ Marzuki (60 tahun), Nazhir Masjid Baitul Mu'minin Kelurahan Baji Mappakasunggu, Wawancara, 9 Juli 2019.

${ }^{37}$ Marzuki (60 tahun), Nazhir Masjid Baitul Mu'minin Kelurahan Baji Mappakasunggu, Wawancara, 9 Juli 2019.

${ }^{38}$ Syaril (50 tahun), Ketua Masjid Darul Ikhlas Kelurahan Tamparang Keke, Wawancara, Tamparang Keke, 9 Juli 2019.
} 
“Disini ada TPA, Remaja masjid, Majelis Taklim, Qurban setiap tahun, dan buka puasa bersama pada bulan ramadhan. Saya rasa baik-baik saja tidak ada kendala" 39

Walaupun telah banyak program-program yang dilakukan, namun menurut pengamatan peneliti, belum terdapat program-program untuk lebih memberdayakan tanah wakaf kearah yang lebih produktif.

e. Nur Alam Saleh Selaku Nazhir Masjid Misbah Salihin

Tanah wakaf yang diatasnya dibangun masjid Misbah Salihin bertempat di jalan Baji Nyawa Kelurahan Karang Anyar Kecamatan Mamajang yang diwakafkan pada tahun 1967. Adapun yang menjadi pengelola (nazhir) masjid Misbah Shalihin adalah Pak Nur Alam Saleh sejak tahun 1996. Pak Alam selaku nazhir tidak mengetahui siapa yang mewakafkan. Tanah wakaf ini juga belum memiliki sertifikat, walaupun Pak Alam sudah berusaha mengurusnya tetapi terkendala di persyaratan administrasi yaitu tidak adanya bukti tertulis pada saat tanah tersebut diwakafkan dikarenakan tanah tersebut diwakafkan hanya lewat lisan. Sebagaimana yang disampaikan oleh Pak Nur Alam Saleh bahwa:

"Tanah wakaf ini tidak ada sertifikatnya. Sudah diurus tapi terkendala di persyaratannya karna dulu wakaf secara lisan saja tidak secara tertulis, jadi sampai sekarang sertifikatnya belum jadijadi. Saya juga tidak tau siapa yang mewakafkan." 40

Sebagamana diamanatkan dalam Pasal 11 Undang-Undang Nomor 41 Tahun 2004 tentang Wakaf bahwa salah satu tugas nazhir adalah melakukan pengadministrasian harta benda wakaf. Pak Alam sudah berusaha mengurus akan tetapi terkendala dipersyaratannya. Secara teknis, pemberian sertifikat tanah wakaf memang membutuhkan keteguhan para nazhir dan biaya yang tidak sedikit. Sehingga diperlukan peran semua pihak yang berkepentingan, khususnya peran Badan Pertanahan Nasional (BPN) dan pemerintah daerah agar memudahkan pengurusannya. ${ }^{41}$

Pak Alam selaku nazhir menjalankan program-program seperti Hari Raya Islam, Shalat Jum'at, Qurban, dan Zakat. Adpun program Zakat diurus langsung oleh UPZ yang dinaungi oleh BAZNAS tidak dicampuri

\footnotetext{
${ }^{39}$ Syaril (50 tahun), Ketua Masjid Darul Ikhlas Kelurahan Tamparang Keke, Wawancara, Tamparang Keke, 9 Juli 2019.

${ }^{40}$ Nur Alam Saleh (59 tahun), Nazhir Masjid Misbah Salihin Kelurahan Karang Anyar, Wawancara, Karang Anyar, 9 Juli 2019.

${ }^{41}$ Direktorat Jenderal Bimbingan Masyarakat Islam dan Penyelenggaraan Haji, Pedoman Pengelolaan dan Pengembangan Wakaf (Jakarta, 2003), h.70-71
} 
oleh pengurus masjid. Sebagaimana yang disampaikan oleh Pak Nur Alam Saleh:

"disini program-programnya itu seperti hari raya Islam, Qurban dan Zakat. Tidak ada kendala apa-apa dalam mengurus masjid. Disini belum ada wakaf produktif." 42

Di masjid ini belum terdapat wakaf produktif dan Pak Alam tidak merasa ada kendala apapun dalam mengelola Masjid Misbah Shalihin.

f. Akmal Selaku Nazhir Masjid Aisyiah

Tanah wakaf yang diatasnya didirikan masjid Aisyiyah bertempat di Jl. Veteran Selatan Lr. 3 Kelurahan Bontolebang. Tanah ini diwakafkan oleh H. Zainuddin sekitar akhir tahun 90an. Pengelola (nazhir) masjid Aisyiah adalah Ustadz Akmal yang telah menjadi nazhir setelah masjid dibangun. Sebagaimana yang disampaikan oleh Ustadz Akmal:

"Setelah tanah diwakafkan lalu dibangun masjid sejak itulah diangkat sebagai pengurus atau pengelola." 43

Ustadz Akmal menjalankan bermacam-macam program di masjid Aisyiah diantaranya adalah Yasinan setiap malam Jum'at, Majelis Taqlim dan TPA sebagaimana yang disampaikan oleh Ustadz Akmal:

“diusahakan selalu ada yasinan setiap malam Jum'at, Pembentukan Majelis Taqlim dan TPA untuk anak-anak dan adapun kendalanya adalah biaya karna masih kurang yang menjadi donatur tetap." 44

H. Zainuddin mengalami kendala dalam mengelola masjid Aisyiah diantaranya adalah kurangnya masyarakat yang menjadi donatur tetap. Hingga sampai saat ini belum terdapat program untuk lebih memberdayakan tanah wakaf, karena program yang dilakukan hanyalah program-program masjid.

\section{g. Ustadz Muhammad Selaku Nazhir}

Menurut informasi awal yang kami dapat dari website resmi Sistem Informasi Masjid.co.id, masjid Nurul Askar yang terletak di Jl. Cendrawasih Komp. Asrama Mattoanging Kel. Pa'batang berdiri diatas tanah wakaf. Namun, saat peneliti terjun langsung kelapangan, Ketua

\footnotetext{
${ }^{42}$ Nur Alam Saleh (59 tahun), Nazhir Masjid Misbah Salihin Kelurahan Karang Anyar, Wawancara, Karang Anyar, 9 Juli 2019.

${ }^{43}$ Akmal (50 tahun), Nazhir Masjid Aisyiah Kelurahan Bonto Lebang, Wawancara, Bonto Lebang, 10 Juli 2019.

${ }^{44}$ Akmal (50 tahun), Nazhir Masjid Aisyiah Kelurahan Bonto Lebang, Wawancara, Bonto Lebang, 10 Juli 2019.
} 
Masjid Nurul Askar tidak mengakui bahwa Masjid Nurul Askar tidak didirikan diatas tanah wakaf. Sebagaimana dikatakan oleh Ketua Masjid Nurul Askar, bahwa:

"Tanah ini bukan tanah wakaf, tapi tanah pinjam pakai" 45

Selain status tanahnya yg tidak jelas, tanah tersebut juga tidak mempunyai pemilik, karena terdapat dua pihak yang mengklaim tanah tersebut sebagai tanah miliknya. Seperti yang disampaikan oleh Muhammad, bahwa:

"Status tanah ini masih tarik ulur, ada satu pihak yang mengklaim bahwwa tanah tersebut miliknya, disi lain pihak Kodam juga mengklaim tanah tersebut" 46

Hingga saat ini, belum ada kejelasan sipa pemilik tamah yangg sebenarnya, dan yang bisa dipastikan oleh ketua Masjid Nurul Askar bahwa status tanah tersebut bukan tanah wakaf.

h. Drs. H. Sanrusseng Selaku Nazhir Masjid Nurul Jihad

Tanah wakaf yang diatasnya didirikan sebuah Masjid Nurul Jihad ini terletak di Jalan Tupai Kelurahan Bonto Biraeng Kecamatan Mamajang. Tanah wakaf ini merupakan tanah wakaf dari Bapak Sirajuddin yang diberikan sekitar tahun 90an. Adapun pengelola tanah wakaf ini (nazhir) ialah Drs.H.Sanrusseng yang diangkat menjadi nazhir pada tahun 1994. Sebagaimana yang disampaikan oleh Bapak Drs. H. Sanrusseng:

“Saya diangkat menjadi nazhir pada tahun 1994" 47

Walaupun telah menjadi nazhir dari tahun 1994, Drs.H.Sanrusseng sebagai seorang nazhir mengatakan bahwa tanah wakaf yang dibangunkan mesjid diatasnya ini belum mempunyai sertifikat. Sebagaimana yang disampaikan oleh Bapak Drs. H. Sanrusseng:

"Saya sudah berapa kali ajukan pengadaan sertifikat tapi sampai sekarang belum ada" 48

\footnotetext{
${ }^{45}$ Muhammad (53 tahun), Nazhir Masjid Nurul Askar Kelurahan Pa'batang, Wawancara, Pa'batang, 10 Juli 2019.

${ }^{46}$ Muhammad (53 tahun), Nazhir Masjid Nurul Askar Kelurahan Pa’batang, Wawancara, Pa'batang, 10 Juli 2019.

${ }^{47}$ H. Sanruseng (75 tahun), Nazhir Masjid Nurul Jihad Kelurahan Bontobiraeng, Wawancara, Bontobiraeng, 9 Juli 2019.

${ }^{48}$ H. Sanruseng (75 tahun), Nazhir Masjid Nurul Jihad Kelurahan Bontobiraeng, Wawancara, Bontobiraeng, 9 Juli 2019.
} 
Adapun pengelolaan tanah wakaf ini masih memiliki beberapa kendala. Namun hal itu tidak menjadi masalah besar karena dapat diselesaikan bersama-sama. Sebagaimana yang dikatakan oleh beliau:

"Kalau kendala pasti ada tapi kita semua sama-sama mengatasinya dan program tanah wakaf ini terdiri dari Majelis Taklim dan TPA" $^{\prime 4}$

Sampai saat ini program yang dilaksanakan hanya terbatas sampai pengadaan Majelis Taklim dan TPA, serta belum terdapat program yang dapat menunjang pemberdayaan tanah wakaf kearah yang lebih produktif.

\section{i. Isla Idris Selaku Nazhir Masjid Nurul Falah}

Tanah wakaf yang diatasnya dibangun sebuah Masjid Nurul Falah yang beralamat di jalan Kakatua II Kelurahan Parang Kecamatan Mamajang adalah sebuah masjid yang berada di bawah naungan yayasan. Tanah wakaf ini memiliki sertifikat yang dipegang oleh ketua yayasan. Bapak Isla Idris telah menjadi nazhir selama dua periode. Sebagaimana yang disampaikan oleh pak Isla Idris:

"Ada sertifikatnya tapi dipegang oleh ketua yayasan. Saya sudah menjadi pengelola di masjid ini selama dua periode" ${ }^{\prime 50}$

Pengelolaan tanah wakaf sejauh ini masih sebatas mengadakan kegiatan-kegiatan keagamaan seperti pada hari jumat setiap remaja mesjid memberikan sedekah berupa beras kepada orang-orang yang kurang mampu. Selain itu di masjid tersebut juga mempunyai mobil ambulans yang diperuntukkan untuk warga kelurahan parang jika ada yang meninggal. Sebagaimana yang disampaikan oleh Pak Isla Idris:

“kegiatan-kegiatan keagamaan, setiap hari jumat remaja mesjid membagikan sedekah berupa beras kepada orang-orang yang kurang mampu, di sini juga punya ambulans jadi setiap warga kelurahan parang ini ada yang meninggal ambulans dari mesjid ini di pake" 51

\footnotetext{
${ }^{49}$ H. Sanruseng (75 tahun), Nazhir Masjid Nurul Jihad Kelurahan Bontobiraeng, Wawancara, Bontobiraeng, 9 Juli 2019.

${ }^{50}$ Isla Idris (51 tahun), Nazhir Masjid Nurul Falah Kelurahan Parang, Wawancara, Parang, 9 Juli 2019.

${ }^{51}$ Isla Idris (51 tahun), Nazhir Masjid Nurul Falah Kelurahan Parang, Wawancara, Parang, 9 Juli 2019.
} 
Bapak Isla Idris selaku nazhir seperti Majelis Taklim, TPA, dan Remaja mesjid. Dalam mengelola masjid Nurul Falah bapak Isla Idris mengalami kendala di mana di masjid ini kurang donatur tetap dikarenakan masyarakat sekitar memiliki tingkat ekonomi yang rendah tetapi jika membutuhkan dana yang besar pengurus mengajukan proposal. Sebagaimana yang disampaikan oleh Pak Isla Idris:

“Disini ada majelis taklim, TPA, dan remaja masjid. Tetapi di masjid ini kurang donatur tetap karena masyarakat sekitar sini bisa dibilang ekonominya rendah jadi kalau butuh dana yang besar kita mengajukan proposal" 52

Walaupun demikian, menurut pengamatan peneliti pemberdayaan tanah ini massih berbatas pada keagaamaan dan sosial. Belum ditemukan pemberdayaan tanah wakaf kearah yang lebih produktif.

Masih adanya tanah wakaf yang berlum tersertifikasi sampai saat ini merupakan dampak dari praktek perwakafan yang dilakukan secara lisan yang menggunakan asas saling percaya di masyarakat yang sampai sekarang masih dilakukan dan mengabaikan prosedur yang sudah ada dalam peraturan perundang-undangan. Seperti di beberapa tempat di Kecamatan Mamajang, tanah wakaf belum memiliki sertifikat.

Sebenarnya praktek perwakafan jenis ini sudah tidak relevan dengan perkembangan zaman sekarang ini dimana praktek ini tidak memiliki dasar hukum yang jelas. Oleh karena itu agar tanah wakaf dapat dilindungi dan memiliki kepastian hukum maka sudah seharusnya dilakukan sertifikasi tanah wakaf.

Adapun dalil pengadministrasian tanah wakaf yaitu:

1. Undang-Undang No 41 tahun 2004 pasal 11 butir a nadzir mempunyai tugas sebagai berikut: melakukan pengadministrasian harta benda wakaf. ${ }^{53}$

2. Undang-Undang No 41 tahun 2004 pasal 32 menyebutkan: PPAIW atas nama nadzir mendaftarkan harta benda wakaf kepada instansi yang berwenang paling lambat 7 (tujuh) hari kerja sejak akta ikrar wakaf ditandatangani. ${ }^{54}$

3. Peraturan Pemerintah No 28 tahun 1977 pasal 5 ayat (1): pihak yang mewakafkan tanahnya harus mengikrarkan kehendaknya secara jelas dan tegas kepada nadzir dihadapan pejabat pembuat akta ikrar wakaf yang kemudian menuangkannya dalam bentuk akta

\footnotetext{
${ }^{52}$ Isla Idris (51 tahun), Nazhir Masjid Nurul Falah Kelurahan Parang, Wawancara, Parang, 9 Juli 2019.

${ }^{53}$ Republik Indonesia, Undang-Undang Nomor 41 Tahun 2004, bab II, pasal 11.

${ }^{54}$ Republik Indonesia, Undang-Undang Nomor 41 Tahun 2004, bab II, pasal 32.
} 
ikrar wakaf dengan disaksikan sekurang-kurangnya dua orang saksi. ${ }^{55}$

4. Peraturan Pemerintah No 28 Tahun 1977 pasal 9 ayat (1): pihak yang hendak mewakafkan tanahnya diharuskan datang dihadapan pejabat pembuat akta ikrar wakaf. ${ }^{56}$

Dalil di atas merupakan peraturan yang telah dibuat untuk proses perwakafan, peraturan tersebut dimaksudkan agar pengelolaan wakaf berjalan secara lancar dan tertib. Wajib kiranya bagi setiap pengelola wakaf dalam hal ini nazhir untuk melasanakan proses perwakafan sesuai dengan peraturan yang telah ditetapkan agar masa yang akan datang tidak ada konflik kepentingan. Namun, di Kecamatan Mamajang tidak semua nazhir yang lalai akan sertifikat wakaf, karena ada beberapa nazhir yang sudah melakukan pengajuan sertifikat tapi terhambat dikarenakan terdapat beberapa masalah.

Terkait masalah wakaf produktif, hingga saat ini wakaf produktif di Kecamatan Mamajang belum pernah dilaksanakan. Undang-Undang Nomor 41 Tahun 2004 pasal 42 nazhir bertugas berbunyi: nazhir wajib mengelola dan mengembangkan harta benda wakaf sesuai dengan tujuan, fungsi dan peruntukannya. ${ }^{57}$ Maksud dari Undang-undang nomor 41 tahun 2004 pasal 42 dapat diketahui bahwa wakaf juga dapat dimanfaatkan kearah yang produktif, namun hingga saat ini belum dilaksanakan oleh para nazhir Kecamatan Mamajang.

Oleh karena itu pihak terkait dalam hal ini KUA sebagai PPAIW memang seharusnya melakukan sosialisasi tentang wakaf produktif kepada para nazhir agar tanah wakaf yang berada di Kecamatan Mamajang bisa bermanfaat secara ekonomi. Namun, KUA Kecamatan Mamajang memang tidak pernah melakukan sosialisai terkait wakaf kepada masyarakat ataupun nazhir. Serta, nazhir pun tidak pernah ke KUA untuk menanyakan atau meminta penyuluhan terkait cara pengelolaan harta bemda wakaf. Hal itu sesuai dengan apa yang didapatkan peneliti saat melakukan wawancara di KUA Kecamatan Mamajang.

Seperti di Masjid Nurul Askar, telah terjadi sengketa tanah terhadap tanah wakaf serta tidak adanya kejelasan terkait status tanah masjid tersebut. Persoalan seperti itu tidak boleh dibiarkan begitu saja, nazhir harus mengambil langkah-langkah konkrit untuk menyelesaikan masalah tesebut baik ditempuh dengan cara musyawarah dengan tokoh masyarakat, agama, maupun RT. Musyawarah tersebut dilakukan untuk

\footnotetext{
${ }^{55}$ Republik Indonesia, Peraturan Pemerintah Nomor 28 Tahun 1997, bab II, pasal 5.

${ }^{56}$ Republik Indonesia, Peraturan Pemerintah Nomor 28 Tahun 1997, bab II, pasal 9.

${ }^{57}$ Republik Indonesia, Undang-Undang Nomor 41 Tahun 2004, bab II, pasal 42.
} 
mecari solusi dan kejelasan terhadap status tanah wakaf yang diakui oleh masyarakat setempat sebagai tanah wakaf. Undang-Undang No 41 Tahun 2004 pasal 62 menyebutkan bahwa: Penyelesaian sengketa perwakafan ditempuh melalui musyawarah untuk mencapai mufakat.

Pasal tersebut menjelaskan bahwa apabila terjadi sengketa maka langkah yang harus ditempuh adalah melalui musyawarah, dengan melakukan musyawarah diharapkan dapat mengatasi persoalan yang terjadi.dari hasil musyawarah tersebut harus ditelusuri dari mana asal usul tanah wakaf tersebut. Apabila masih belum ada kejelasan, maka mereka dapat membentuk pengurusan yang baru ataupun kepengurusan yang lama yang sudah berjalan sebelumnya untuk mengelola tanah wakaf tersebut. Hal tersebut dilakukan agar dapat memperkuat status tanah wakaf yang kemudian diberikan kepada nazhir berdasarkan kesepakatan rapat musyawarah tersebut.

Kepastian kepengurusan ini didapat setelah seluruh masyarakat sepakat akan penunjukan nazhir yang baru maupun yang lama. Setelah sepakat akan penunjukan pengelola kemudian akan ditindaklanjuti oleh RT, kemudian melalui keterangan dari RT tentang pengurusnya kemudian dilanjutkan ketingkat kelurahan untuk penerbitan SKT atas nama nazhir tersebut. Langkah selanjutnya adalah melakukan ikrar wakaf dengan mencantumkan surat hasil rapat musyawarah disertai dengan SKT dan kemudian diterbitkanlah akta ikrar wakaf oleh PPAIW di KUA setempat kemudian diajukan ke BPN.

Selain tersebut, jika terjadi pergantian nazhir, para nazhir di Kecamatan Mamajang tidak pernah malapor ke KUA. Hal tersebut jelas dinyatakan oleh pihak KUA bahwa tidak ada seorang nazhir pun yang datang untuk melaporkan bahwa terjadi pergantian nazhir. Persoalan tersebut merupakan problematika yang terjadi di Kecamatan Mamajang yang seharusnya diatasi dan tidak dibiarkan begitu saja karena harta benda wakaf merupakan aset yang harus dijaga dan dipelihara.

\section{Kesimpulan}

Kebanyakan harta benda wakaf yang diwakafkan di Kec. Mamajang adalah tanah atau benda tidak bergerak. Problematika pengelolaan wakaf di Kec. Mamajang adalah masih adanya tanah wakaf yang belum bersertifikat karena adanya kendala pada nazhir dalam pengurusan surat tanah yang tidak ada, hal ini disebabkan karena perwakafan yang dilakukan secara lisan dan tidak diketahuinya keberadaan ahli warisnya. Serta nazhir yang tidak mejalankan tugasnya sesuai dengan undang-undang yang ada. Proses perwakafan yang dilakukan di Kecamatan Mamajang hanya diperuntukkan untuk 
pembangunan sarana ibadah, sehingga hasil yang dicapai dari harta wakaf yang dikelola saat ini belum maksimal karena belum di kelola secara produktif.

\section{Daftar Pustaka}

Badan Wakaf Indonesia (BWI), (04 Juni 2019) "Menengok Potensi Wakaf Di Indonesia", Situs Resmi Badan Wakaf Indonesia, http://www.bwi.or.id/index.php/ar/publikasi/berita-mainmenu109/266-menengok-potensi-wakaf-di-indonesia

Badan Wakaf Indonesia (BWI), (16 Juni 2019) “Aset Wakaf Sangat Besar Tapi Belum Produktif" Situs Resmi Badan Wakaf Indonesia, https://bwi.or.id/index.php/ar/publikasi/artikel/264-aset-wakafsangat-besar-tapi-belum-produktif.html (16

Bisri, Cik Hasan. Pilar-Pilar Penelitian Hukum Islam dan Pranata Sosial. Jakarta : Grafindo Persada, 2004.

Brenen, Julia. Memadu Metode Penelitian : Kualitatif dan Kuantitatif. Yogyakarta : Pustaka Pelajar, 2005.

Kasdi, Abdurrahman. "Peran Nadzir dalam Pengembangan Wakaf", Jurnal Zakat dan Wakaf1, No. 2, Desember, 2014.

Marzuki, Peter Mahmud. Penelitian Hukum, Cet. Ke-7. Jakarta: Kencana, 2011.

Meleong, Lexy J. Metodologi Penelitian Kualitatif Edisi Revisi, Cet. Ke-22. Bandung : PT Remaja Rosdakarya, 2006.

Naim, Abdul Haris, Desember 2017, "Pengembangan Obyek Wakaf Dalam Fiqig Islam Dan Hukum Positif Di Indonesia", Ziswaf 4, No. 2.

Rahman, Asmak Ab 2009, "Peranan Wakaf dalam Pembangunan Ekonomi Umat Islam dan Aplikasinya di Malaysia", Jurnal Syariah 17, No. 1.

Republik Indonesia, Peraturan Pemerintah Nomor 28 Tahun 1997.

Republik Indonesia, Peraturan Pemerintah Nomor 42 Tahun 2006.

Republik Indonesia, Undang-Undang Nomor 41 Tahun 2004.

Silalahi, Gabriel Amin. Metode Penelitian dan Studi Kasus. Sidoarjo : Citra Media, 2003. 
Sudirman. Januari, 2010, "Studi Perbandingan Obyek Wakaf Menurut Fiqih Dan Undang-Undang Wakaf", Fakultas Syariah UIN Maliki Malang 1, No. 2.

Suwaidi, Ahmad. 2011, "Wakaf dan Penerapannya di Negara Muslim”, Jurnal Ekonomi dan Hukum Islam 1, No. 2.

Zuriah, Nurul. Metodologi Penelitian Sosial dan Pendidikan. Jakarta : Bumi Aksara, 2006.

Bungin, Burhan. Penelitian Kualitatif: Komunikasi, Ekonomi, Kebijakan Publik, dan Ilmu Sosial lainnya. Jakarta : Kencana Prenada Media Group, tt.

Usman, Husaini; Purnomo Akbar, Metodelogi Penelitian Sosial, Cet. Ke-6. Jakarta: Bumi Aksara, 2006. 